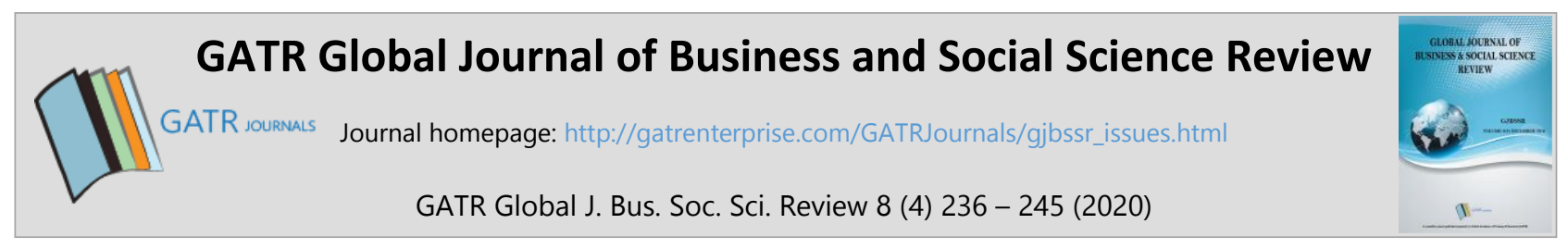

\title{
Exploring the Significance of Stakeholder Management in Ecotourism Implementation
}

\author{
Ahmad Salman', Mastura Jaafar², Diana Mohammad ${ }^{3}$ \\ ${ }^{1}$ PhD Researcher School of Housing Building \& Planning, University Sains Malaysia, Malaysia \\ ${ }^{2,3}$ Faculty of Housing Building \& Planning, University Sains Malaysia, Malaysia
}

\begin{abstract}
Objective - Ecotourism is one of the fastest-growing sectors of tourism. It is considered to be an alternative to mass tourism. The negative impacts, such as loss of biodiversity and loss of natural resources is confronted with the help of ecotourism. For the past years, stakeholders are considered to be vital for ecotourism implementation. Successful implementation of the ecotourism is not possible without the understanding, involvement and management of the stakeholders. Stakeholder management is vital for the successful ecotourism implementation in the destination, but it is not as simple as it sounds. Even though many types of research have been made on the issue of achieving ecotourism sustainability in tourism destination but there is still a lack of a robust and proper model that can assist in the management of stakeholders which can help to unify stakeholders to achieve sustainable ecotourism in the destination. Therefore, the aim of this study is to explore the importance of identifying stakeholder management significance that can enhance stakeholder interests to unify them towards achieving sustainable ecotourism in the destination.

Methodology/Technique - Content analysis was done, and the study concludes that in order to manage stakeholders, their engagement has to be well planned by understanding their interests and level of influence. Twenty-one articles were selected and analyzed from Scopus and Web of Science databases.

Finding - The management of the stakeholders varies accordingly to the destination due to which it has to be carefully planned so that sustainable ecotourism can be implemented in the destination. Stakeholders understanding will provide a win-win situation for the destination and make the ecotourism implementation process smoother. Moreover, the study also fills in the theoretical gap of the analysis of the studies, which is a part of a significant contribution towards ecotourism implementation in a destination.
\end{abstract}

Type of Paper: Review

JEL Classification: D63, G12, G14.

Keywords: Stakeholder Management, Engagement, Ecotourism, Sustainable Ecotourism

Reference to this paper should be made as follows: Salman, A; Jaafar, M; Mohammad, D. (2020). Endeavours: Exploring the significance of stakeholder management in ecotourism implementation, GATR Global J. Bus. Soc. Sci. Review, 8(4): 236 - 245. https://doi.org/10.35609/gjbssr.2020.8.4(5)

\section{Introduction}

Ecotourism plays a major role in boosting the economy (Krce Miočić, Razović, \& Klarin, 2016; Abdullah et al., 2018).

\footnotetext{
${ }^{*}$ Paper Info: Revised: July 24, 2020

Accepted: December 31, 2020

* Corresponding author: Ahmad Salman

E-mail: ahmadsalman@student.usm.my

Affiliation: PhD Researcher School of Housing Building \& Planning, University Sains Malaysia, Malaysia
} 
It not only helps to create jobs but also provides an alternate source of living for the people (Pongponrat \& Chantradoan, 2012). Ecotourism offers great benefits to the host area, but its successful implementation is not simple and is considered to be challenging because of the involvement of the multi-stakeholders in a tourist destination (Üllenberg et al., 2015). Implementing sustainable ecotourism practices in the destination is impossible without understanding and managing of the stakeholders. Stakeholder management is the systematic identification, analysis, planning and implementation of actions designed to engage stakeholders. The utility of the stakeholder management in tourism originates from the foundation that successful implementation and planning of any project depends on the involvement of different stakeholders like organizations, groups and individuals who are impacted by that project or they have the ability to influence that project (Lalicic, 2018; Komppula, 2016; Wei \& Yang, 2013; Bashir, 2012; Dabphet et al., 2009).

Even though stakeholder management and the development of the management strategies are recognized as an essential step to achieve the sustainable ecotourism (Getz \& Timur, 2005) and many researchers have also emphasized on the importance of the stakeholder management to attain sustainable ecotourism in the destination, yet there is no specific study that combines the literature of the stakeholder management importance in ecotourism implementation and presents it in one study. Therefore, this study tries to address this gap by reviewing the literature on stakeholder management importance in ecotourism implementation to improve the knowledge and understanding of the stakeholder management importance for ecotourism implementation.

The structure of the paper is as follows: first, the authors introduced the main problem in the introduction part as well as the research objective. Second, the authors explored the past literature in the literature review. Then methodology and the review process of this paper was discussed. Data analysis was done after that followed by results and analysis. Lastly, the conclusion is presented for the complete paper.

\section{Literature Review}

Even though there are many different views regarding ecotourism, but it is commonly agreed that ecotourism helps to conserve resources, develop community and enhance tourism in the destination and protect the environment (Su et al., 2014). Ecotourism involves multiple goals and also incorporates multiple stakeholders with different interests, roles and responsibilities (Shams 2012, Liu et al. 2013). The concept of stakeholders emerged a long time ago by Freeman (2010), and its significance is now realized by almost all disciplines. There are stakeholders involved in tourism destination also. The concept of stakeholders assumes that a destination takes central place within the relationship network of other interests and influential groups to make sure that the destination can exist for a long term where the stakeholder is each person that can influence or can be influenced by meeting goals of destination (Krce Miocic et al., 2016; V. M. Waligo et al., 2014). Stakeholders have multiple interests, influential power, demands and problems related to the destination in which they are involved, and they need to be tackled carefully and appropriately (Salman et al., 2020).

Moreover, sustainable development implementation in a destination depends on the involvement and interests of all stakeholders. The main aim of understanding stakeholders is to identify the potential interests, their level of influence, involve the key stakeholders of the destination and guide to increase key stakeholders participation to provide prosperity to the destination (Krce Miocic et al., 2016). Some of the main problems that hinder the implementation of sustainable ecotourism also occur because of the stakeholders of the destination.

The literature of tourism also highlights on the inclusion of the stakeholder identification, interest understanding, power estimation and management techniques for improving the relationships of stakeholders (Ryan, 2002; Sheehan \& Ritchie, 2005; Timur \& Getz, 2008). The complex tourism system makes stakeholder management challenging. Therefore, understanding the multi-stakeholder destination management concept by utilizing the stakeholder theory is of vital importance. The stakeholder theory can help to guide on the understanding of the multiple stakeholders and how their management can lead towards

GATR Global J. Bus. Soc. Sci. Review 8 (4) 236 -245 (2020) 
the long-term success of the destination. Each stakeholder has a different perspective and goals in the destination due to which stakeholders should be harmonized towards achieving sustainability in the destination (Krce Miocic et al., 2016).

\section{Methodology}

This section represents the methodology to conduct this study. It incorporates all the strategies, eligibility criteria, sources and analysis to conduct this study. For the study design, content analysis of the articles was performed in order to identify the importance of stakeholder management in ecotourism implementation. This study focused on one main question which was

What is the significance of stakeholder management in ecotourism implementation?

\subsection{Inclusion and exclusion criteria}

Selected studies that showed the relationship between stakeholder management and ecotourism implementation were selected for the analysis. These studies ranged from the year 2001 to 2019. Nineteen years timeline is an acceptable timeframe for establishing the relationship between the two variables (Shaffril et al., 2018). This study only considered articles that were based on peer-reviewed journals. Additional parameters are shown in table 1 below

Table 1: Inclusion \& Exclusion criteria

\begin{tabular}{|c|c|c|}
\hline Criterion & Eligibility & Exclusion \\
\hline Type of literature & Peer-reviewed journal articles & $\begin{array}{c}\text { Expert opinions, meeting abstracts, case } \\
\text { reports conference proceedings. }\end{array}$ \\
\hline Timeline & Between 2001 and 2019 & Non-English \\
\hline Language & English & Non peer reviewed \\
\hline Indexes & $\begin{array}{l}\text { Social Science Citation Index, Emerging Sources } \\
\text { Citation Index, Art and Humanities Index (WOS) }\end{array}$ \\
\hline
\end{tabular}

Source: Adapter from Shaffril et al. (2018)

\subsection{Information \& Search Strategies}

The search technique was developed with the help of the authors in consultation with a reference group. The selection of the articles was associated with the terms such as "Ecotourism", "stakeholder management", "stakeholder management strategy" and "sustainable ecotourism". Web of Science and Scopus were the major databases researched for conducting this study. The reason for selecting these databases was that the Scopus databases contain over 22,800 journals and web of science consists of 33,000 journals from 256 various disciplines.

\subsection{Review Process}

The review process of this study consisted of four phases. First, keywords were identified which were related to the studies regarding stakeholder management, ecotourism and sustainable ecotourism. The figure 1 below explains the review process 


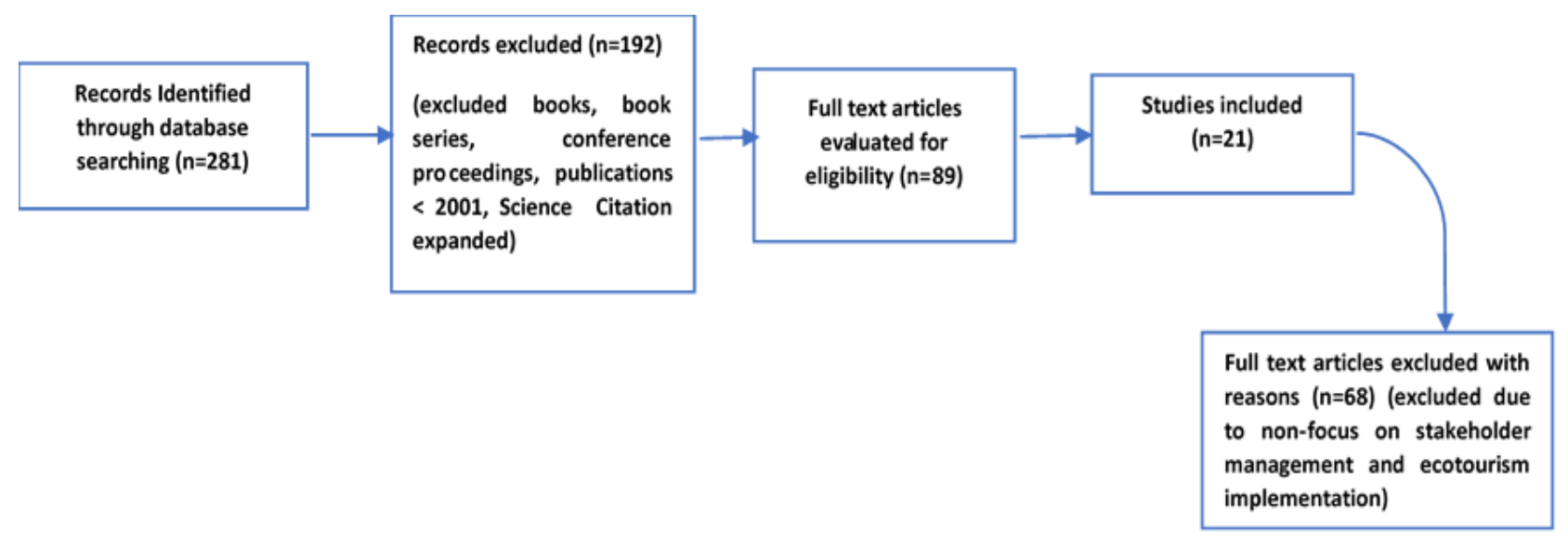

Figure 1: Flow of review of Stakeholder management significance in ecotourism implementation (Adapted from Moher et al., 2009)

\section{Data analysis}

The finalized papers were analyzed and reviewed. First of all, the data was extricated by reviewing the abstracts, then the full papers to understand the study and do the content analysis for this study. The selected articles selected covered different regions of the world such as Asia, Europe and Africa. The shortlisted articles were analyzed in order to understand the importance of stakeholder management in ecotourism implementation, as shown in Table 2.

Table 2: Literature for content analysis

\begin{tabular}{|c|c|c|}
\hline Authors & Region & Content Analysis \\
\hline $\begin{array}{l}\text { Hardy \& } \\
\text { Beeton } \\
(2001)\end{array}$ & Australia & $\begin{array}{l}\text { Understanding stakeholders and proper management is vital for developing } \\
\text { sustainable tourism. } \\
\text { Stakeholder management helps circumvent conflicts between groups, unifying } \\
\text { them and also conserve resources }\end{array}$ \\
\hline $\begin{array}{l}\text { Sheehan \& } \\
\text { Ritchie } \\
(2005)\end{array}$ & Canada & $\begin{array}{l}\text { The stakeholders' identification, assessment and management is vital for a } \\
\text { tourism destination success. } \\
\text { Implementation of proper management strategies to unite the stakeholders is } \\
\text { vital for the success of the destination. } \\
\text { Developing a positive relationship with the stakeholders is crucial for the } \\
\text { destination success. }\end{array}$ \\
\hline TG Ko (2005) & Korea & $\begin{array}{l}12 \text { case studies were analysed to understand the issues in sustainable tourism } \\
\text { development. } \\
\text { The stakeholders should be included in the planning and decision making of the } \\
\text { destination, for tourism sustainability in the destination. } \\
\text { Stakeholders should be involved, engaged and managed for ecotourism to occur } \\
\text { in the destination. }\end{array}$ \\
\hline $\begin{array}{l}\text { Koutsouris } \\
(2009)\end{array}$ & Greece & $\begin{array}{l}\text { Stakeholders understanding is vital for sustainable tourism. } \\
\text { Stakeholders should be facilitated and appropriately managed in order to } \\
\text { achieve long term sustainable tourism in the destination. }\end{array}$ \\
\hline Mezei (2009) & Romania & $\begin{array}{l}\text { Stakeholder management is a vital for tourist destination management. } \\
\text { The final plan that is set in action is the result of the efforts of all the } \\
\text { stakeholders involved in a certain tourism area. } \\
\text { All participants (stakeholders) are expected to take part in the activities that help } \\
\text { to make a destination successful, due to which their management is essential. }\end{array}$ \\
\hline $\begin{array}{l}\text { Wei \& Yang } \\
\quad(2013)\end{array}$ & China & $\begin{array}{l}\text { The ecotourism implementation often fails due to lack of understanding of the } \\
\text { stakeholders' interests. } \\
\text { Primary stakeholders interests and relationships should be carefully managed for } \\
\text { the implementation of the ecotourism in the destination. }\end{array}$ \\
\hline Waligo, & UK & The lack of stakeholder management leads to the failure of sustainable tourism \\
\hline
\end{tabular}

GATR Global J. Bus. Soc. Sci. Review 8 (4) $236-245$ (2020) 


\begin{tabular}{|c|c|c|}
\hline $\begin{array}{l}\text { Clarke, \& } \\
\text { Hawkins } \\
(2013)\end{array}$ & & $\begin{array}{l}\text { in the destination. } \\
\text { Stakeholders play an important role in achieving sustainable tourism. } \\
\text { A tourism destination involves multi-level stakeholders which can impact the } \\
\text { destination positively or negatively. } \\
\text { To achieve sustainable tourism, especially ecotourism in the destination, } \\
\text { stakeholders should be managed and appropriately engaged in the destination. }\end{array}$ \\
\hline $\begin{array}{c}\mathrm{Su}, \text { Wall, \& } \\
\mathrm{Ma}(2014)\end{array}$ & China & $\begin{array}{l}\text { The ecotourism destination Xingkai Lake National Nature Reserve in } \\
\text { Heilongjiang Province, China observes multiple stakeholder management for } \\
\text { successful ecotourism. } \\
\text { The power structure and management structure should be properly managed for } \\
\text { the stakeholders to be united. }\end{array}$ \\
\hline $\begin{array}{l}\text { Zehrer \& } \\
\text { Hallmann } \\
\quad(2015)\end{array}$ & Austria & $\begin{array}{l}\text { This study points out the importance of stakeholders in achieving sustainable } \\
\text { tourism. } \\
\text { The stakeholders" management and policies should be carefully planned as they } \\
\text { are indicators of sustainable tourism destination. }\end{array}$ \\
\hline $\begin{array}{l}\text { Nicolaides } \\
\text { (2015) }\end{array}$ & South Africa & $\begin{array}{l}\text { The stakeholders can become a hindrance in the project success and thus should } \\
\text { be carefully engaged in a tourism destination. } \\
\text { Stakeholders can positively and negatively influence the project. } \\
\text { Strong efforts should be made to positively identify and engage stakeholders } \\
\text { that can have an influence on the project. }\end{array}$ \\
\hline $\begin{array}{l}\text { Božena Krce } \\
\text { Miočić, Mili } \\
\text { Razović, \& } \\
\text { Tomislav } \\
\text { Klarin (2016) }\end{array}$ & Croatia & $\begin{array}{l}\text { Tourism brings a lot of positive outcomes for a country. } \\
\text { The researchers point out that the stakeholders' importance cannot be ignored. } \\
\text { Destination consists of multiple stakeholders and understanding their interests } \\
\text { and influence is vital for achieving sustainability in the destination. }\end{array}$ \\
\hline $\begin{array}{l}\text { Pjerotić, } \\
\text { Rađenović, \& } \\
\text { Tripković- } \\
\text { Marković } \\
\text { (2016) }\end{array}$ & Montenegro & $\begin{array}{l}\text { Including diverse stakeholders in the planning of a tourism destination is very } \\
\text { important for its success. } \\
\text { Diverse stakeholders can have a vast variety of interests. } \\
\text { Stakeholders engagement and collaboration should be carefully planned so that } \\
\text { the stakeholders can be properly managed. }\end{array}$ \\
\hline $\begin{array}{l}\text { Van Cuong, } \\
\text { Dart, \& } \\
\text { Hockings } \\
(2016)\end{array}$ & Australia & $\begin{array}{l}\text { Researchers stress on the importance of stakeholders in achieving sustainability } \\
\text { success in a biosphere reserve. } \\
\text { Stakeholder participation and collaboration, governance, finance and resources, } \\
\text { management, and awareness and communication are the most influential factors } \\
\text { in the success or failure of the biosphere reserves. }\end{array}$ \\
\hline $\begin{array}{l}\text { Wang, Cater, } \\
\& \text { Low (2016) }\end{array}$ & Taiwan & $\begin{array}{l}\text { The stakeholders have different goals and influence level so they have to be } \\
\text { understood and managed properly. } \\
\text { More multi-focused approach was required to tackle with the stakeholders to } \\
\text { implement sustainable ecotourism in the destination. } \\
\text { The management of the stakeholders is crucial for the implementation of the } \\
\text { stakeholders. }\end{array}$ \\
\hline $\begin{array}{l}\text { Lee, Kim, \& } \\
\text { Kwon (2017) }\end{array}$ & Korea & $\begin{array}{l}\text { The ecotourism planning requires a balance between conservation and } \\
\text { development. } \\
\text { Stakeholders interests regarding ecotourism should be mapped out for } \\
\text { ecotourism planning. } \\
\text { The difference in opinions can make the stakeholders diverge away from the } \\
\text { path of ecotourism implementation so it is very important to understand them } \\
\text { and manage them. }\end{array}$ \\
\hline $\begin{array}{l}\text { Kenawy, } \\
\text { Osman, \& } \\
\text { Alshamndy } \\
\quad(2017)\end{array}$ & Egypt & $\begin{array}{l}\text { In Egypt, plans related to sustainable tourism failed because stakeholders' } \\
\text { interests were not understood, and their conflicts were not resolved. } \\
\text { The stakeholders' engagement was not done properly and is just being used as a } \\
\text { token. } \\
\text { It is because of this lack of understanding and uneven distribution of power, the } \\
\text { sustainable ecotourism implementation fails. }\end{array}$ \\
\hline $\begin{array}{l}\text { Van Cuong, } \\
\text { Dart, Dudley, }\end{array}$ & Australia & $\begin{array}{l}\text { The stakeholders' awareness and engagement is vital for achieving sustainability } \\
\text { especially in the biosphere reserve. }\end{array}$ \\
\hline
\end{tabular}

GATR Global J. Bus. Soc. Sci. Review 8 (4) 236 -245 (2020) 


\begin{tabular}{|c|c|c|}
\hline $\begin{array}{c}\text { \& Hockings } \\
(2018)\end{array}$ & & $\begin{array}{l}\text { Weak engagement of the stakeholders will lead to failure for developing } \\
\text { sustainability. } \\
\text { A multi-stakeholder model especially that involves the public and private } \\
\text { stakeholders cannot work unless there is proper management of the } \\
\text { stakeholders. }\end{array}$ \\
\hline $\begin{array}{l}\text { Osman, } \\
\text { Shaw, \& } \\
\text { Kenawy } \\
(2018)\end{array}$ & Egypt & $\begin{array}{l}\text { Researchers state that if the stakeholders are not managed, and they do not have } \\
\text { a collaboration, then they will have an unbalanced relationship. } \\
\text { The more effectively, stakeholders are engaged and participate in a project, the } \\
\text { more chances of success of a project. More engagement will help them to } \\
\text { achieve more collaboration also. } \\
\text { Understanding of stakeholder's network and engaging them in the planning } \\
\text { process from the start will help to implement ecotourism successfully. }\end{array}$ \\
\hline $\begin{array}{l}\text { Ayala-orozco } \\
\text { et al. (2018) }\end{array}$ & Mexico & $\begin{array}{l}\text { The complex environmental problems that hinder sustainability in the tourism } \\
\text { destination require great attention. } \\
\text { Stakeholders collaboration is required to address these issues, and stakeholder } \\
\text { collaboration cannot be achieved if there is no stakeholder management. } \\
\text { Management of the stakeholders to ensure that they partner and collaborate for } \\
\text { achieving sustainability is vital for a tourism destination. }\end{array}$ \\
\hline $\begin{array}{l}\text { Litheko \& } \\
\text { Potgieter } \\
\text { (2019) }\end{array}$ & South Africa & $\begin{array}{l}\text { Strategic stakeholder management will bring positive economic and social } \\
\text { benefits for the area and will help in achieving sustainable ecotourism. } \\
\text { Management of the stakeholders helps anticipate the stakeholders' reaction to } \\
\text { project and how to gather their support. }\end{array}$ \\
\hline $\begin{array}{l}\text { Rifky Edo \& } \\
\text { Sambas } \\
\text { (2019) }\end{array}$ & Indonesia & $\begin{array}{l}\text { The stakeholder management by developing adequate strategies is vital in } \\
\text { ecotourism implementation. } \\
\text { The researchers state that understanding the interests and influence of the } \\
\text { stakeholders is critical for successful implementation of ecotourism. } \\
\text { Stakeholders management can optimize the area to provide benefits to } \\
\text { stakeholders. }\end{array}$ \\
\hline
\end{tabular}

\subsection{Stakeholder management significance for ecotourism implementation}

Ecotourism is a complex concept but a powerful economic force. Knowing that ecotourism involves multiple goals, it automatically involves stakeholders with varied interest, influences and roles (Shams, 2012; Liu, Li, \& Pechacek, 2013). In order to implement ecotourism successfully, stakeholders must be involved and managed in the process (Su et al., 2014).

Stakeholder management is vital for the implementation and operationalization of ecotourism in the destination. Stakeholders are considered to be the leading players in the ecotourism implementation, and their management affects ecotourism growth (Backman \& Munanura, 2015; Pasape et al., 2013; Marulo, 2012). Stakeholder management is done through engagement, empowerment and monitoring. Stakeholder engagement requires working together with the stakeholders to understand their needs, meet their expectations and resolve issues as they occur during the implementation of the ecotourism in the destination. Waligo et al. (2013) points out that the engagement of stakeholders is vital for achieving the ecotourism sustainability in the destination. Different stakeholders have different interests or perspectives and their engagement in the ecotourism implementation will help to identify their level of interest, influence, involvement capacity and relationships with other stakeholders which is vital for the successful implementation and operationalization of the ecotourism in the destination (Waligo et al., 2013).

Researchers over the past years have also noted that the engagement combined with stakeholders empowerment will lead to better management of stakeholders which as a result will lead to efficient ecotourism implementation in the destination (Almudi \& Berkes, 2010; Cobbinah, Amenuvor, Black, \& Peprah, 2017). Moreover, capacity building of the stakeholders along with proper training will help to make sure that the stakeholders are well aware and trained of the ecotourism principles which will not only help to pave the path for smooth ecotourism implementation but will also help to reduce the negativity among the stakeholders (Adina Nicoleta Candrea \& Herțanu, 2015; Rivera et al., 2018). 
Another important dimension for stakeholder management as pointed by the literature is the monitoring of stakeholders. Researchers such as Waligo et al. (2013) and Pasape et al. (2013) have also highlighted that the monitoring of stakeholders is vital in achieving sustainable ecotourism in the destination. Adequate monitoring and follow up on stakeholders are considered to be one of the strategic planning techniques required for successful implementation of ecotourism in the destination (McCool, 2014). Proper monitoring and support for stakeholders will also help to smoothen up the ecotourism implementation process and identify many different factors such as stakeholders level of participation, level of awareness, stakeholders relationship with each other and stakeholders support for ecotourism development which are vital for ecotourism implementation in the destination.

It was also observed from the literature that the understanding of the interests and influences of the multiple stakeholders is not as simple as it sounds. Multiple stakeholders in a project such as ecotourism implementation have different interests and influences, making their management even more challenging (Lee et al., 2017; Kenawy et al., 2017; Osman, Shaw, \& Kenawy, 2018; Yang, 2014). Analyzing the stakeholders interests and influence provides the starting point on which a proper stakeholder management strategy could be developed, and identify which stakeholders in the project could be influenced accordingly to make a project successful (Van Cuong et al., 2018; Noto \& Noto, 2018; Byrd et al., 2008). Lack of proper stakeholder's management strategy can lead to the failure of the ecotourism implementation. Without the proper management of stakeholders, ecotourism implementation can be difficult. Lack of understanding of stakeholder management dimensions such as stakeholder engagement and empowerment was identified to be two of the significant issues which were considered to be hindering the ecotourism implementation in the destination (Wang et al., 2016; Wei \& Yang, 2013).

\section{Results \& Discussion}

This study concluded that stakeholder management significance in ecotourism studies; however, scattered makes the importance of the stakeholders' management very clear. Out of the 21 selected studies, two studies were from 2019, three studies were published in 2018, two studies in 2017, four studies in 2016, two studies in 2015, two studies for each year of 2005, 2009, 2013 and one study in each 2014 and 2001 respectively.

The content analysis done in this study indicated that stakeholder management is vital for ecotourism implementation in any region. Effective stakeholder management not only helps to deal with the groups that can have a substantial impact on the project but also with those groups that can be impacted by the project(Harrison \& Freeman, 2015)(Harrison \& Freeman, 2015)(Harrison \& Freeman, 2015)(Harrison \& Freeman, 2015)(Harrison \& Freeman, 2015)(Harrison \& Freeman, 2015)(Harrison \& Freeman, 2015). In implementing ecotourism, stakeholder theory suggests taking the functional approach for implementation of the ecotourism whereby the proper management of the stakeholders will yield substantial economic growth for the economy while minimizing the environmental pollution and cultural destruction. The literature recommends on understanding the interests and influence power first and then focus on stakeholder management that can lead to the successful implementation of ecotourism in the region. After reviewing the literature, stakeholder engagement was found to be the best technique to manage the stakeholders. Stakeholders positive engagement, empowerment and monitoring, is vital in the successful ecotourism implementation in the destination.

Sometimes, stakeholder management is complex and full of issues, especially when it comes to the collaboration of the different stakeholder groups with different interests and influence power. A vast number of stakeholders and their interests should be considered in order to make stakeholder involvement and management successful. The fact that the stakeholders involved in the ecotourism implementation can influence the tourism development in many ways like supply, demand, regulation, human resources and management of the area. This portrays the importance of stakeholder management in the implementation of the ecotourism. Furthermore, the majority of the issues that hamper the sustainable ecotourism development in the area are related to the stakeholders such as priorities, organization or resource related. So, the

GATR Global J. Bus. Soc. Sci. Review 8 (4) 236 -245 (2020) 
management of the stakeholders should be carefully planned for the development of the ecotourism in the region.

\section{Conclusion}

Multiple stakeholders are involved in the implementation of ecotourism, so it is vital to manage stakeholders accordingly to their interests and influence. Effective management for the stakeholders, especially the primary stakeholders such as community, organizations, the government can contribute towards conserving resources, protecting the environment and generating suitable economic activities for the region (Nicolaides, 2015). Moreover, the strategic management of the stakeholders can also develop support for the region and create a type of environment that helps the community to grow (Nicolaides, 2015).

Understanding different factors such as stakeholders influence, stakeholders interests and stakeholders support involved the in the management of the stakeholders will help to manage stakeholders efficiently towards the sustainable ecotourism development (Waligo et al., 2013; Zehrer \& Hallmann, 2015). This will help to develop the strategic focus and collaboration of these stakeholders shift towards the sustainable ecotourism implementation plan that will promote economic activities, protect the environment and increase social benefits in the region.

The current study provides some important theoretical and practical contributions. First, by doing an indepth literature review and content analysis of the literature, the investigation has contributed towards an ongoing discussion about understanding the role of stakeholders in achieving ecotourism sustainability. From the perspective of the practitioner, the current study offers valuable guidelines to understand stakeholders which can come in useful for the policymaker, planner and management of the destination.

\section{Acknowledgement}

The authors would like to thank the Universiti Sains Malaysia (USM) for supporting this research under the USM Fellowship Scheme and Research Grant, School of Housing Building and Planning, Universiti Sains Malaysia (Grant no: 1001/PPBGN/8016053).

\section{References}

Abdullah, A. R., Weng, C. N., Afif, I., \& Fatah, A. (2018). Ecotourism in Penang National Park: a multi-stakeholder perspective on environmental issues. J Bus Soc Dev, 6(1), 70-83.

Almudi, T., \& Berkes, F. (2010). Barriers to empowerment: fighting eviction for conservation in a southern Brazilian protected area. Local Environment, 15(3), 217-232.https://doi.org/10.1080/13549830903575570

Ayala-Orozco, B., Rosell, J. A., Merçon, J., Bueno, I., Alatorre-Frenk, G., Langle-Flores, A., \& Lobato, A. (2018). Challenges and strategies in place-based multi-stakeholder collaboration for sustainability: Learning from experiences in the Global South. Sustainability, 10(9), 3217. https://doi.org/10.3390/su10093217

Krce Miočić, B., Razovič, M., \& Klarin, T. (2016). Management of sustainable tourism destination through stakeholder cooperation. Management: journal of contemporary management issues, 21(2), 99-120.

Byrd, E. T., Cárdenas, D. A., \& Greenwood, J. B. (2008). Factors of stakeholder understanding of tourism: The case of Eastern North Carolina. Tourism and Hospitality Research, 8(3), 192-204.https://doi.org/10.1057/thr.2008.21

Candrea, A. N., \& Hertanu, A. (2015). Developing ecotourism destinations in Romania. A case study approach. Bulletin of the Transilvania University of Brasov. Economic Sciences. Series V, 8(2), 163.

Cobbinah, P. B., Amenuvor, D., Black, R., \& Peprah, C. (2017). Ecotourism in the Kakum Conservation Area, Ghana: Local politics, practice and outcome. Journal of outdoor recreation and tourism, 20, 34-44. https://doi.org/10.1016/j.jort.2017.09.003

Freeman, R. E. (2010). Strategic management: A stakeholder approach. Cambridge university press. https://doi.org/10.1017/CBO9781139192675

Getz, D., \& Timur, S. (2012). 12 Stakeholder involvement in sustainable tourism: balancing the voices. Global tourism, 230. https://doi.org/10.1016/b978-0-7506-7789-9.50019-4 
Hardy, A. L., \& Beeton, R. J. (2001). Sustainable tourism or maintainable tourism: Managing resources for more than average outcomes. Journal of Sustainable tourism, 9(3), 168-192. https://doi.org/10.1080/09669580108667397

Harrison, J. S., Freeman, R. E., \& Abreu, M. C. S. D. (2015). Stakeholder theory as an ethical approach to effective management: Applying the theory to multiple contexts. Revista brasileira de gestão de negócios, 17(55), 858-869. https://doi.org/10.7819/rbgn.v17i55.2647

Kenawy, E., Osman, T., \& Alshamndy, A. (2017). What Are the Main Challenges Impeding Implementation of the Spatial Plans in Egypt Using Ecotourism Development as an Example? Social sciences, 6(3), 75. https://doi.org/10.3390/socsci6030075

Ko, T. G. (2005). Development of a tourism sustainability assessment procedure: a conceptual approach. Tourism management, 26(3), 431-445. https://doi.org/10.1016/j.tourman.2003.12.003

Komppula, R. (2016). The role of different stakeholders in destination development. Tourism review. https://doi.org/10.1108/TR-06-2015-0030

Koutsouris, A. (2009). Social learning and sustainable tourism development; local quality conventions in tourism: A Greek case study. Journal of Sustainable Tourism, 17(5), 567-581.https://doi.org/10.1080/09669580902855810

Krce Miočić, B., Razovič, M., \& Klarin, T. (2016). Management of sustainable tourism destination through stakeholder cooperation. Management: journal of contemporary management issues, 21(2), 99-120.

Lalicic, L. (2018). Open innovation platforms in tourism: how do stakeholders engage and reach consensus?. International Journal of Contemporary Hospitality Management. https://doi.org/10.1108/IJCHM-04-2016-0233

Lee, J. H., Kim, S. H., \& Kwon, H. S. (2017). Mapping Interests by Stakeholders' Subjectivities toward Ecotourism Resources: The Case of Seocheon-Gun, Korea. Sustainability, 9(1), 93.https://doi.org/10.3390/su9010093

Litheko, A., \& Potgieter, M. (2019). Strategic Management of Tourism Stakeholders: Bakgatla-ba-Kgafela, South Africa. African Journal of Hospitality, Tourism and Leisure, 8(2).

Liu, C., Li, J., \& Pechacek, P. (2013). Current trends of ecotourism in China's nature reserves: A review of the Chinese literature. Tourism Management Perspectives, 7, 16-24. https://doi.org/10.1016/J.TMP.2013.03.001

Mezei, K. A. (2009). Tourist destination management. Revista de turism-studii si cercetari in turism, (8), 52-58.

Nicolaides, A. (2015). Tourism Stakeholder Theory in practice: instrumental business grounds, fundamental normative demands or a descriptive application?.

Nopiansyah, F., \& Basuni, S. (2017). Forest Resource Utilization Siberut Community and ts Implications by the i for the Policy Siberut Island Biosphere Reserve. Jmht, 23(December), 180-191. https://doi.org/10.7226/jtfm

Noto, G., \& Noto, L. (2019). Local strategic planning and stakeholder analysis: Suggesting a dynamic performance management approach. Public Organization Review, 19(3), 293-310. https://doi.org/10.1007/s11115-018-0403-0

Osman, T., Shaw, D., \& Kenawy, E. (2018). Examining the extent to which stakeholder collaboration during ecotourism planning processes could be applied within an Egyptian context. Land Use Policy, 78, 126-137. https://doi.org/10.1016/j.landusepol.2018.06.043

Pjerotić, L., Rađenović, M., \& Tripković-Marković, A. (2016). Stakeholder Colaboration in Tourism Destination Planning-The Case of Montenegro. Economics, 4(1), 119-136. https://doi.org/10.1515/eoik-2015-0026

Pongponrat, K., \& Chantradoan, N. J. (2012). Mechanism of social capital in community tourism participatory planning in Samui Island, Thailand. Tourismos, 7(1).

Rivera, J. P. R., \& Gutierrez, E. L. M. (2019). A framework toward sustainable ecotourism value chain in the Philippines. Journal of Quality Assurance in Hospitality \& Tourism, 20(2), 123-142. https://doi.org/10.1080/1528008X.2018.1492495

Salman, A., Jaafar, M., \& Mohamad, D. Strengthening Sustainability: A Thematic Synthesis of Globally Published Ecotourism Frameworks. https://doi.org/10.46222/ajhtl.19770720-16

Shams, A. (2012). Towards a quantification model: the accountability of the for-profit and non-profit organisations in the High Mountains of Sinai Peninsula. International Journal of Tourism Anthropology, 2(3), 185-212. https://doi.org/10.1504/ijta.2012.050758

Sheehan, L. R., \& Ritchie, J. B. (2005). Destination stakeholders exploring identity and salience. Annals of Tourism Research, 32(3), 711-734. https://doi.org/10.1016/j.annals.2004.10.013

Su, M. M., Wall, G., \& Ma, Z. (2014). Assessing ecotourism from a multi-stakeholder perspective: Xingkai lake national nature reserve, China. Environmental management, 54(5), 1190-1207. https://doi.org/10.1007/s00267-0140360-5

Üllenberg, A., Buchberger, C., Meindl, K., Rupp, L., Springsguth, M., \& Straube, B. (2015). Evaluating Cross-Border Natural Resource Management Projects. 
Van Cuong, C., Dart, P., Dudley, N., \& Hockings, M. (2018). Building stakeholder awareness and engagement strategy to enhance biosphere reserve performance and sustainability: The case of Kien Giang, Vietnam. Environmental management, 62(5), 877-891. https://doi.org/10.1007/s00267-018-1094-6

Van Cuong, C., Dart, P., \& Hockings, M. (2017). Biosphere reserves: Attributes for success. Journal of Environmental Management, 188, 9-17. https://doi.org/10.1016/j.jenvman.2016.11.069

Waligo, V. M., Clarke, J., \& Hawkins, R. (2014). The 'leadership-stakeholder involvement capacity'nexus in stakeholder management. Journal of Business Research, 67(7), 1342-1352. https://doi.org/10.1016/j.jbusres.2013.08.019

Waligo, V. M., Clarke, J., \& Hawkins, R. (2013). Implementing sustainable tourism: A multi-stakeholder involvement management framework. Tourism management, 36, 342-353. https://doi.org/10.1016/j.tourman.2012.10.008

Wang, C. C., Cater, C., \& Low, T. (2016). Political challenges in community-based ecotourism. Journal of Sustainable Tourism, 24(11), 1555-1568. https://doi.org/10.1080/09669582.2015.1125908

Wei, M., \& Yang, R. R. (2013). A Research on Eco-tourism Development Models Based on the Stakeholder Theory. In Applied Mechanics and Materials (Vol. 291, pp. 1447-1450). Trans Tech Publications Ltd. https://doi.org/10.4028/www.scientific.net/amm.291-294.1447

Yang, R. J. (2014). An investigation of stakeholder analysis in urban development projects: Empirical or rationalistic perspectives. International Journal of Project Management, 32(5), 838849.https://doi.org/10.1016/j.ijproman.2013.10.011

Zehrer, A., \& Hallmann, K. (2015). A stakeholder perspective on policy indicators of destination competitiveness. Journal of Destination Marketing \& Management, 4(2), 120-126.https://doi.org/10.1016/j.jdmm.2015.03.003 